\title{
Crooked Neck-Like Protein 1
}

National Cancer Institute

\section{Source}

National Cancer Institute. Crooked Neck-Like Protein 1. NCI Thesaurus. Code C143051.

Crooked neck-like protein 1 (848 aa, $100 \mathrm{kDa}$ ) is encoded by the human CRNKL1 gene.

This protein is involved in splicing of pre-mRNA. 